\title{
Ethnologies
}

\section{Touring An Other's Reality: Aboriginals, Immigrants, and Autochromes}

\section{Colleen Skidmore}

Volume 26, numéro 1, 2004

Littératie

Literacy

URI : https://id.erudit.org/iderudit/013344ar

DOI : https://doi.org/10.7202/013344ar

Aller au sommaire du numéro

Éditeur(s)

Association Canadienne d'Ethnologie et de Folklore

ISSN

1481-5974 (imprimé)

1708-0401 (numérique)

Découvrir la revue

Citer cet article

Skidmore, C. (2004). Touring An Other's Reality: Aboriginals, Immigrants, and Autochromes. Ethnologies, 26(1), 145-164. https://doi.org/10.7202/013344ar
Résumé de l'article

Durant l'été de 1914, une famille autochtone nord-américaine et un immigrant allemand ont réalisé (et laissé) un enregistrement de leur rencontre sur la rive de la rivière Saskatchewan Nord à Edmonton, Alberta. Il a pris la forme de deux autochromes de $5 \times 7$ pouces, photographies $3 / 4$ couleur sur plaque de verre. Cet article explore la manière dont ces fragiles autochromes rendent visible ce qui a été rarement entrevu, l'espace historique partagé par la famille autochtone et le photographe immigré à qui de la place avait été faite par traité. Peu importe le point de vue duquel on les examine, ces images se trouvent présenter l'histoire que la culture colonialiste européenne racontait sur elle-même, histoire dans laquelle autant les autochtones que les immigrants étaient parties intégrantes. Aujourd'hui, argumente cet article, ces autochromes signalent ce qui se voyait quand un immigrant et des déplacés de l'intérieur ont rencontré, et soutenu, le regard l'un de l'autre.
Ce document est protégé par la loi sur le droit d'auteur. L’utilisation des services d’Érudit (y compris la reproduction) est assujettie à sa politique d'utilisation que vous pouvez consulter en ligne.

https://apropos.erudit.org/fr/usagers/politique-dutilisation/ 


\title{
Touring An Other's Reality: Aboriginals, IMMIGRANTS, AND AUTOCHROMES
}

\author{
Colleen Skidmore \\ Department of Art and Design, University of Alberta ${ }^{1}$
}

“...essentially the camera makes everyone a tourist in other people's reality, and eventually in one's own" (Barthes 1981: 110).

In the summer of 1914, a North American Aboriginal family mother, father, daughter - and a German immigrant photographer made (and left) a record of their encounter on the bank of the North Saskatchewan River in Edmonton, Alberta. It took the form of two $5 \times 7$ " autochromes - colour glass-plate transparencies - one of which is now badly damaged (see figures 1 and 2) 2 $^{2}$. If we conceive of the West as "a cultural crossroads... formed through exchanges among many different people," as Elizabeth Jameson and Susan Armitage do, then this image presents the opportunity, as those writers urge, to "imagine how a common historical space appeared from many different lines of sight" $(1997: 9,5)$. If it is agreed that the shared geographical and temporal space registered by the photograph can be counted "a common historical space," - but not a "contact zone" of interchange (Pratt 1992: 4) nor a hybrid, newly structured "third space" (Rutherford 1990: 211), both a product of sustained interaction - then the image offers two discrete lines of sight that are viewed less often. For as Lucy Lippard has written, "most literature about tourism is written from the standpoint

1. Fiona McDonald and Don Cooper's research assistance with this project is gratefully acknowledged.

2. The autochrome was the first colour photographic technology. Invented by the Lumière brothers in France in 1904, it was used until about 1914 (Wood $1993)$. 
of the visitor... rather than that of the visited. [...] Immigrants and the internally displaced are rarely asked how they see their surroundings. Yet every place is both local and foreign" (Lippard 1999: 2). Rarer still is an opportunity such as this to explore views of the common historical space traversed by the internally displaced and an immigrant for whom room was made through treaty.

This project began as an examination of a European immigrant photographer's use of colour to document the spectacle of a legendary West of Indians, scouts, and mounted police, which he found on his arrival just prior to the First World War, and how his images integrated archaic but ingrained ideas of the day about middle-class European family life and taming of the North American West (Skidmore 2003). Emerging towards the end of that study was a tension between traditional imaginings of "Indianness," as documented in an autochrome of Native American performers in Buffalo Bill's Wild West, and the photographer's encounter with real, contemporary Aboriginals living on the margins of a modern West. The subject matter and pictorial aesthetic comprising the family portraits suggested that the immigrant photographer, like the displaced subjects of the autochrome, was entangled by pre-existing racial and cultural assumptions about indigenous peoples and destabilized by his encounter with their reality. The photographer was among tens of thousands enticed by a solicitation for immigrants from central and eastern Europe and the United States to settle on the Canadian prairies in the early twentieth century, making it an extraordinarily diverse cultural crossroads. And yet, as Franca Iacovetta, editor of A Nation of Immigrants (1998) reminds us, "immigrant recruitment and settlement... often has been contingent on the displacement and subjugation of Canada's First Nations" (1998: xii). And so, the Aboriginal family's material contributions to the image surely equal to that of the photographer, as they deflected his gaze in posterity - fractured the focus of the original inquiry and forced a critical analysis of the image as the product of an exchange of gazes.

At first glance, the family autochromes read as classically ethnographic images common in the early twentieth century: frontally composed with details of Aboriginal faces, hair, and clothing fully on display (and in full colour), and centrally framed from an observant distance rather than at an interactive proximity between the examining viewer and the indigenous subjects who stand on barren land. The family is isolated on this patch of dirt, seemingly stranded in an environment 


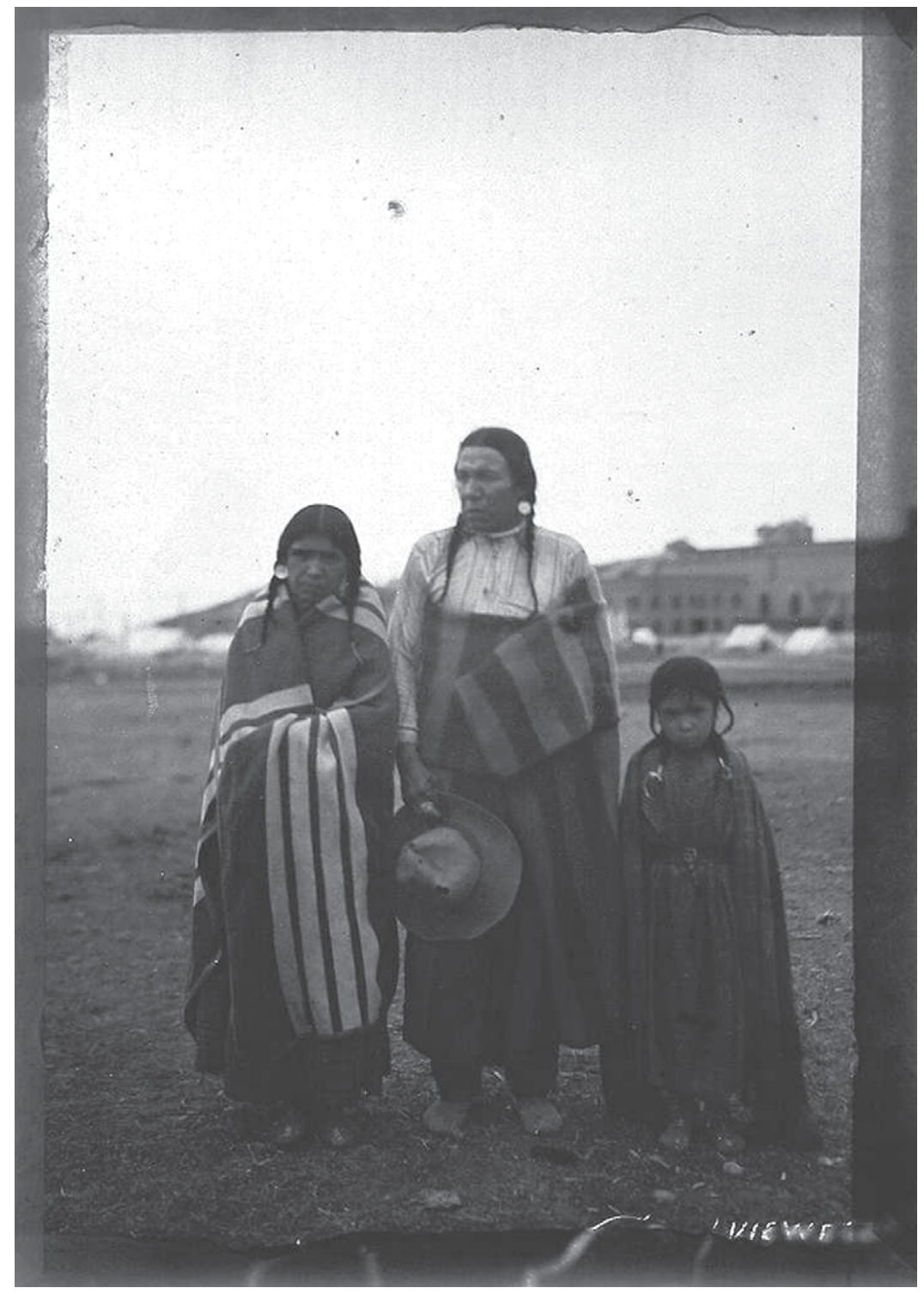

Figure 1. Hugo Viewegar, Aboriginal Family, autochrome, 1914. Edmonton, with permission of the Provincial Archives of Alberta (PR2000.1304.3). 
once their own but no longer so: brick buildings and tents, not teepees, are their backdrop. Almost a century later, however, the ethnographic imperative of these images is less vigorous. Mindful of James Clifford and George E. Marcus's contention in Writing Culture that "ethnography... [is] caught up in the invention, not the representation of cultures" (1986: 2) ${ }^{3}$ and Susan Sontag's claim that photographers invent the past $(1973: 6)$, it becomes apparent from the subjects' presentation of themselves - their poses, expressions, gestures, and accoutrements - that these images portray as much about the photographer as the family, as much about the culture hovering behind the camera as the one exposed in front of the lens, as much about an immigrant's experience as that of indigenous people in their common historical space. When understood in this light, under pressure of a postcolonial reclamation of indigenous peoples' agency in visual productions of colonial relations, ${ }^{4}$ the powerful one-way stare of early twentieth century ethnographic photographs fractures when the early twenty-first century viewer casts a look. Reading the autochromes as the product of a cognizant exchange of those involved in the encounter is key to parsing the complex of meanings and knowledge made in these images.

In the well-conserved image, the family variously resists our gaze: the woman wraps her blue and white trade blanket around her, obscuring our view of her body or clothing, except for the skirt hem and moccasins beneath; her head is tucked toward her shoulder, her gaze directed at the camera, photographer, and viewer, but her expression is closed. ${ }^{5}$ The man, whose clothes are also on display but reveal little more typical early twentieth century Plains native dress of shirt, trousers, hat

3. To illustrate their argument about ethnographic writing, Clifford and Marcus use a photograph of an ethnologist writing notes. Relying on a photograph for documentary authority, they ironically if inadvertently fail to apply their critical insights to visual constructions of cultures.

4. Photography was first introduced to Aboriginals and Métis on the prairies by Humphrey Lloyd Hime during the Canadian government's 1858 Assiniboine and Saskatchewan Expedition.

5. As part of treaty annuity payments in Canada, Hudson's Bay trade blankets were received by every Native person (Tichenor 2002: 43). The acceptance of blankets as partial treaty payment is not specified in Treaty Six, however. The blankets worn by this family appear to be American trade blankets possibly made by the Pendleton Woolen Mills in Oregon. The roles and significance of trade blankets in visual culture and identity in Canada is the subject of Fiona McDonald's forthcoming master's thesis at the University of Alberta. 
and multicoloured blanket (red, orange, green, blue) - looks away from the camera in much the same way that Aboriginal men were typically cast in paintings and photographs gazing into the distance, but here the expression is closed also, the look more defiant, resistant, or indifferent than contemplative, with no feathered headdress, skin clothing, or beads in sight. His face is weathered, lined, and lived-in, displaying neither youthful and idealized beauty nor grotesque and savage ruggedness. The girl, whose red and black plaid blanket is about her shoulders leaving her calico dress on display, seems to retreat from the camera, her chin too bent down and no smile on her face. In short, this family appears to refuse the performance of display for the camera.

The contradiction in this image - the subjects' seeming compliance with being photographed and yet refusal to portray anything of themselves - both entices and confounds the contemporary viewer's desire to know these people's individual identities and histories. And yet, in keeping with the family's own desires perhaps, the contradiction does force today's viewer to look, if only obliquely, along an Aboriginal line of sight out of the picture and back at the photographer, his surroundings and his location in their common historical space. In his short essay "Their Shadows Before Them: Photographing Indians," Louis Owens argues that tourist photographs of indigenous inhabitants function in paradoxical ways: for indigenous people who are subjects, the photographs become illustrations in the story that the photographing culture tells about itself (2003: 191). It is in this way that the autochromes refute the one-way gaze of ethnographic classicism and in so doing depict as much about the immigrant as the family. For example, a comparison of the intact autochrome with the other now-damaged plate demonstrates that pictorialist aesthetic concerns were at play in picturing these people: significant compositional differences, especially in the family's arrangement and the man's pose, suggest the photographer's considered intervention in the composition for the sake of visual impact. ${ }^{6}$ Conversely, such images ultimately, Owens argues,

6. Viewegar's aesthetic grounding was pictorialism, an approach to photography as a fine art practice rather than scientific aid or mechanical tool practiced widely in Germany by Viewegar's contemporaries and advocated strongly in North America by American photographer Alfred Stieglitz whom Viewegar met in Paris. The tenets of pictorialism at the turn of the twentieth century included photography's independence as an artistic form of expression adhering to fine art principles of composition, abstract concerns with beauty and nature, exploration and manipulation of photographic media, artists' subjectivity, and symbolism. 
"play a crucial role in giving a people a picture of themselves... Admittedly... filtered through the lens of the dominant, invasive, culture... but nonetheless what adheres is the living air of a people and a culture" (2003: 192).

The names of the family members, their band, and tribe remain unknown because any oral or written accounting that may have been made of the encounter is absent. The lack of defining accoutrements, especially traditional clothing decoration or style of teepee, compounds the problem. While the moccasins might offer a clue (Wissler 1975: 104-114), the details of their cut and decorative pattern are not clear enough to allow identification. It is likely that they were members of one of the largest tribes in the Edmonton area, Plains or Woodland Cree, whose common ancestors had immigrated from the Ontario and Québec region to the western prairies and parkland in the late seventeenth century. The Cree had migrated in response to new economic opportunities and endeavours as trappers and traders, pursuing furs along the Red and Saskatchewan Rivers for trade with the Hudson's Bay Company. HBC trading posts followed the Cree, including Fort Edmonton established in 1795, an economically — and culturally - vibrant crossroads located near the site of this photographic encounter until 1915, when Fort Edmonton was finally dismantled.?

Comprehending the disparity of the Aboriginal family's line of sight with that of the immigrant photographer is possible when we consider the disparate historical viewpoints on the treaty made between the Cree and the British Crown and which made possible the encounter photographed. In 1871, four Cree chiefs of what is now Saskatchewan and central Alberta, concerned about non-Native appropriation of land and diminishing buffalo stock, requested to treat with the lieutenantgovernor of the Northwest Territories. Chief Sweet Grass stated that "We heard our lands were sold and we did not like it; we don't want to sell our lands; it is our property, and no one has a right to sell them. Our country is getting ruined of fur-bearing animals, hitherto our sole support, and now we are poor and want help..." (Morris 1991: 170-171). Treaty Six was subsequently negotiated in 1876. In exchange for sharing the

7. Today the area, known as Rossdale Flats, is a contested site between the municipal power utility that occupies the land and Aboriginals, Métis, and others defending its sacred and archeological integrity (Gregoire 2001: B1; Howell 2004a; Howell 2004b). 


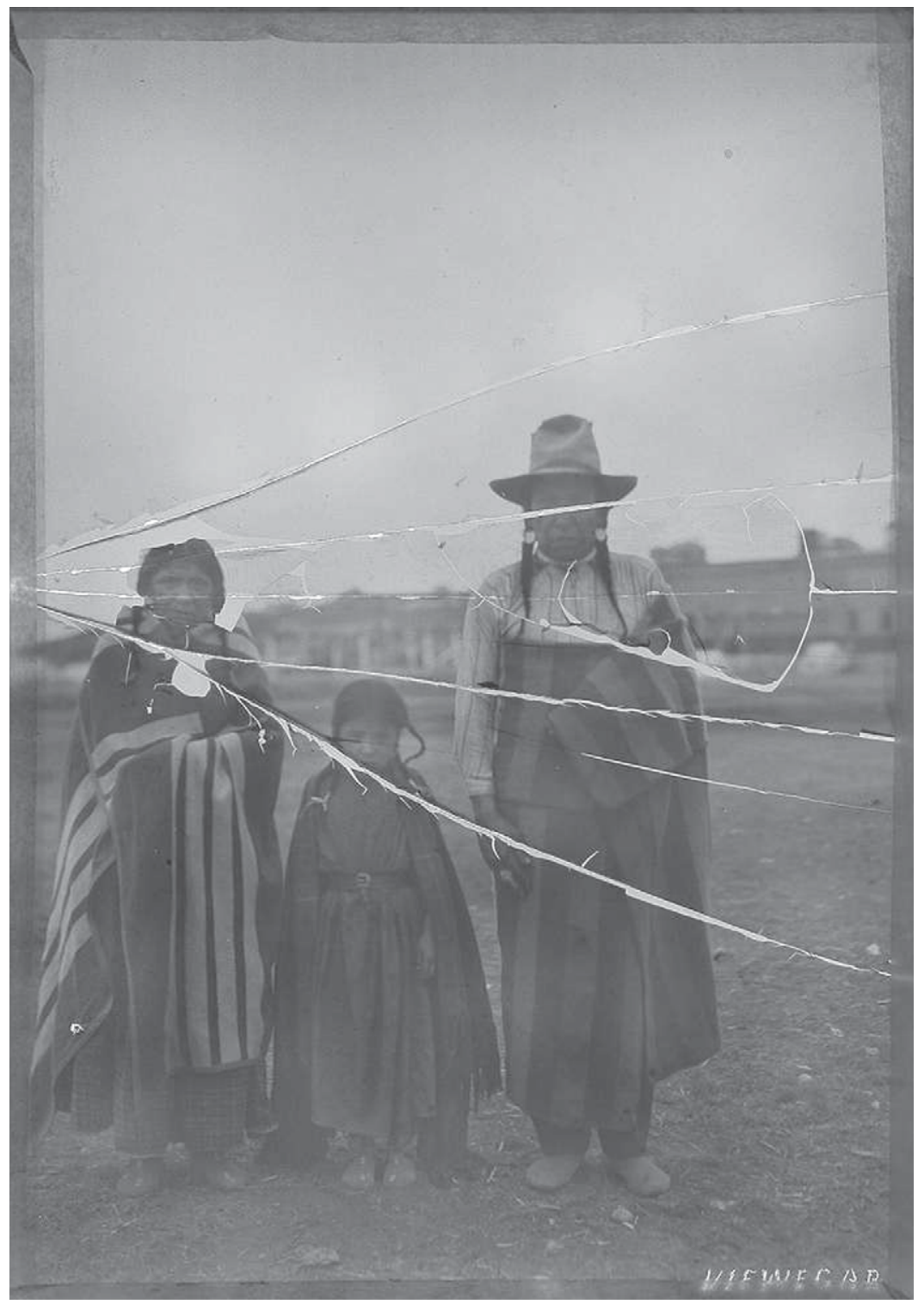

Figure 2. Hugo Viewegar, Aboriginal Family, autochrome, 1914. Edmonton, with permission of the Provincial Archives of Alberta (PR2000.1304.9). 
land with immigrant settlers for the purpose of agriculture, the Cree negotiated reserved land for settlement and farming, treaty money, education, and farming implements. Signed in the face of the imminent decimation of the buffalo herds, as well as a smallpox infestation, this treaty is distinguished from earlier numbered treaties by providing for a medicine chest for the reserves and financial aid in times of famine or epidemic. $^{8}$

Andrew Gray, who accompanied a United Nations Special Rapporteur to a forum with Treaty Six Elders in 1989, explains that the difference between the two sides in the Treaty "was in the form of the two powers - state power vs. spirit power" (IWGIA 1997: 28). The difference would seem to abide in the understandings of the significance of the Native pipe ceremony that opened negotiations: whereas the Cree negotiators understood the ceremony to mark the treaty as a statement of truth, the government negotiators understood it, as they would their own sworn oaths on the Bible, as a statement of "sincerity of intent" quite separate from the treaty itself (IWGIA 1997: 47). Gray argues that

When the Chiefs signed the Treaty in 1876, they did something which
was sacred and could not be changed. [...] The spirit world was fused
into the Treaty through the sacred pipe ceremony. Now the political
and spiritual aspects of the Treaty are equally important. Rather than
being reducible to each other, they mutually co-exist and are coeval.
[...] It enables us to understand both the sense in which the Treaty
would have been understood by the indigenous signatories as well as
to analyze the context of negotiations and the written account of the
agreements (IWGIA 1997: 50-51).

At the forum, Elder Marcus Sparklingeyes of Goodfish Lake First Nation, recounting Elders' inherited oral knowledge of the treaty, stated that

The whiteman did not buy our lands. He made a Treaty, as long as the sun shines and the waters flow. It should be that way now, since he asked our forefathers for the use of the land. There were many Chiefs present at the time of the Treaty-signing. On both sides there an understanding was reached. This is our land and nobody else can own

8. Even reserved land was lost after treaties. In 1890, for example, declining numbers forced the surrender of the Papachase band's reserve land southeast of Edmonton (now known as the suburb of Mill Woods) for homesteading (Dempsey 1986: 56). 
our land, because the Creator put us here... The way we understood the Treaty. We gave only the top soil to the whiteman for his use to survive on this land of ours (IWGIA 1997: 69-70).

Cree negotiators who neither spoke nor read English relied on interpreters to represent their points accurately. Two of the Crown negotiators reportedly were conversant in Cree and corrected the interpreters as needed (Morris 1991: 178). Elder Michael Fineday of Witchekan Lake First Nation stated, however, that

... the unfortunate part of it was this: there was no person to monitor the activities of the people who were translating. Changes were made. Some things that were not said or even mentioned were imposed upon our people in the English version of the Treaty.

If you look at the Elders' view of the Treaty and then look at the written version of the Treaty, we will never recognise anything, even if it is the same document. [...] We would never surrender our lands... We shared our lands and did not surrender them (IWGIA 1997: 73).

And yet, the written text explicitly cedes — or claims — the nonreserved land:

And whereas the said Commissioners have proceeded to negotiate a treaty with the said Indians, and the same has been finally agreed upon and concluded as follows, that is to say:

The Plain and Wood Cree Tribes of Indians, and all other the Indians inhabiting the district hereinafter described and defined, do hereby cede, release, surrender and yield up to the Government of the Dominion of Canada for Her Majesty the Queen and her successors forever, all their rights, titles and privilege whatsoever to the lands included within the following limits... (Morris 1991: 352; IWGIA 1997: 122).

Although neither Elders' oral accounts of the negotiations nor government representatives' written accounts explicitly recount discussions about selling or ceding land (IWGIA 1997: 26-27), the English language text version of the treaty appears to reveal what Gray calls the "hidden agenda" of the state power to obtain land.

Such cultural and historical differences of expectations, aspirations, and understanding are inherent in the autochromes made by the family and photographer. As members of a tribe that had agreed with the British Crown to share its land with a third group, immigrant settlers, this family's control of their response to the newcomer's gaze and his 
desire for a visual document of their encounter suggest divergent expectations of the purpose and outcome of the exchange. For while the immigrant's photograph would seem to document the indigenous family's reality, Owens's argument suggests that the image also documents the immigrant's reality in this common historical space.

The photographer was Hugo Viewegar, a 39-year-old resident of Leipzig who immigrated to the prairies with his wife, Luise, and their three children in 1912. He was a man of considerable means, a prosperous second-generation international financier who imagined and sought out the life of a country gentleman in a colonial space (a way of life reportedly inspired during recovery from an unspecified illness at a rural sanatorium in Germany in 1911 [Vieweger 2001: 19]). As such, Viewegar was the ideal prospect for those promoting immigration to Canada during the first decade of the twentieth century. The Canadian prairie was not his first choice, however. The family had tried their hand at life in German Southwest Africa (Namibia) for six months, but turned to the British Empire and its promises of prosperity when material conditions in Africa proved too hard for the well-to-do family.

In 1912, the Viewegars joined tens of thousands of immigrants from central and eastern Europe who responded to Canadian and British appeals for settlers to homestead 160 acres of free land on the Canadian prairies. Kanada: Das Land der Gelegenheit, a publication of the Canadian government's Department of the Interior, demonstrates the enticements offered to potential German immigrants. The 32-page pamphlet, casting Canada as "the Land of Opportunity," was directed specifically at "farmers, farm labourers, railways construction men and female domestic servants" (trans., n.p.). Kanada features a full-colour cover page with two photographs of a bountiful wheat harvest against a background of autumnal maple leaves. While the pamphlet covers all of Canada, its emphasis is clearly on the West. Scattered through the narrative are nine black-and-white photographs depicting rural scenes from across the country, but focused mainly on the prairies. The one exception to the rural theme is an elevated view of Winnipeg. The opening description of the human and physical geography, furthermore, is accompanied by a photograph portraying two Caucasian men with a team of horses stooking grain while harvesting near Edmonton. The pamphlet concludes with a detailed coloured map, including rivers, railways, cities and towns, of the Dominion of Canada, Newfoundland, and the northern United States. 
Kanada is a translation and adaptation of three similar editions published for the United Kingdom market between 1908 and 1910. In this version, the area of the prairies is compared to that of the German Empire, as roughly equal at 200,000 square miles (7). Twenty-one testimonials from German immigrants living in the three prairie provinces are persuasive endorsements for the veracity of promises of opportunity and prosperity awaiting the farmer immigrant. Two of these were from the community of Stony Plain, 32 kilometres west of Edmonton, where the Viewegars first settled. The farmers cite abundant harvests on their 160 acres of free farmland, such as 2000 bushels on 65 cultivated acres and 2500 bushels on 132 acres respectively, along with farm buildings valued at between $\$ 2000$ and $\$ 5000$ (26). Given the visual evidence of bountiful harvests, modern equipment, and teamwork in the accompanying photographs, the Viewegars' decision to settle in a predominantly German community near Edmonton was well founded.

Kanada advised potential immigrants that "the proper time to reach Canada is between the beginning of April and the end of September" (trans., 2). The Viewegars arrived in spring 1912 in Stony Plain, but by 1913 had moved to Edmonton when Hugo's health problem returned and prevented him from farming. The modern, prosperous, industrializing city proved an ideal place and opportunity for Viewegar to benefit financially from his longtime avocation of photography, itself a modern, industrial enterprise. Exceptional economic prosperity and population growth that had marked Edmonton in the decade following its incorporation as a city in 1904 culminated in the summer of 1914 when Viewegar was making his autochromes. The city had been named capital of the new province of Alberta in 1905, and established academic, cultural, and industrial institutions in the next few years sparking a construction boom and rapid economic and social expansion. Among the projects fueling the city's growth were the Beaux-Arts style provincial legislative building constructed on the north bank of the river above Fort Edmonton, the first buildings of the new University of Alberta campus facing the legislature from across the river on the elevated south bank, as well as the Canadian Pacific Railway's steel High Level bridge linking the two banks and allowing for rail, vehicular, and pedestrian traffic. This was accompanied by construction of the CPR's traditional chateau-style Hotel Macdonald to provide first-class accommodation for rail passengers. The decade's cultural and industrial growth was accompanied by a ninefold increase in the 1904 population 
of 8350. In 1911, the Census of Canada recorded the population of Edmonton as 24,900 people, $67 \%(16,727)$ of whom were of British origins. German immigrants made up the next largest group at $6.6 \%$ (1647 residents) of the city's population, and eight residents, or .03\% of the population, were Aboriginals. By the time Viewegar moved to Edmonton in 1913, the population had risen to 67,243, and in 1914, on the eve of the First World War, reached 72,516 people (City n.d.).

Viewegar opened a studio downtown on Jasper Avenue, advertising on his business card "Artistic Portraiture, Natural Color Photography, and Commercial Work." Because of the outbreak of war with Germany, he was in business for little more than a year, and few of his photographs survive. No advertising or critical commentary on his studio or photographs is to be found in the local papers or photography trade journals of the day, and in the absence of a census during that year of business nothing of the details of his commercial practice can be gleaned. It is understood, however, that his work did garner local support as he was commissioned to photograph the outgoing Governor General, the Duke of Connaught, and his family during their final visit to Edmonton in July of 1914. A consequence of this commission, however, was that many of his studio assets were seized and disposed of when Britain declared war on Germany less than two weeks later. As a German immigrant, Viewegar's recent proximity to state dignitaries raised security concerns (Vieweger 2001: 24).

The absence of recorded contemporary response to Viewegar's practice, especially his autochromes, complicates this study. That he advertised colour work on his card, however, suggests that it was a distinguishing characteristic of his studio, set up at a time when the small city's commercial photography market was highly competitive with at least 32 active commercial photographers (Phillips 1997: 1317). Who saw the images or whom Viewegar intended to see them perhaps family and friends in Germany on a return visit, customers in his studio, other photographers in the area - is unknown and so any kind of public meaning they may have carried in 1914 is gone.

Making an autochrome was a specialized and comparatively expensive undertaking. Few photographers produced them and it is believed that only a few hundred survive worldwide. Viewegar learned the process from the inventors themselves, the Lumière brothers of France, shortly after they introduced the format in 1904. Furthermore, 
the autochrome was a rarely seen image, a direct positive that could not be printed on paper nor replicated as a transparency. Because it was not reproducible, its image could not be widely circulated or viewed and so held little financial potential for the commercial photography trade. In contrast, the singularity of the autochrome medium lent itself well to a pictorialist's fine art photography practice and Viewegar counted himself among pictorialists in Germany prior to trying his hand at commercial photography in Edmonton (Vieweger 2001: 18). Not only were autochromes one of a kind, Viewegar's work was a one-of-akind practice on the prairies at the time. This makes them all the more interesting in light of the sepia-toned aura that washes over posterity's knowledge and imagining of the historical West. Thomas King observes in The Truth about Stories: a Native Narrative, an examination of EuroNorth Americans' conceptions of Aboriginal people, that "tripping the shutter captures nothing... What the camera allows you to do is invent, to create. That's really what photographs are. Not records of moments, but rather imaginative acts" (2003: 43). The expectations of the West that informed Viewegar's choice of subject matter for the images, then, give us our best understanding of their original meaning for a European or Euro-Canadian viewer.

Had the autochromes been seen in Germany by those who had not visited the Canadian or American prairies, they would have been startling for their unique colour rendering of the West. Viewegar made the only known colour photograph of Buffalo Bill's Wild West troupe of Native American performers, the first-known colour photograph of a Royal Northwest Mounted Police officer dressed in red serge and posing alongside his horse, (both members of the Musical Ride which like the Wild West performed in Edmonton in the summer of 1914 [figures 3 and 4]), and these two images of an Aboriginal family, living remnants of the original societies of the prairies encountered in the urban environment of settler immigrants. ${ }^{9}$ The first two images would seem to confirm that Viewegar had found, and was living in, the legendary West of European imagination, with the colourful, exotic characters of Indians and mounted police in full dress - even though these figures were

9. In total, ten Viewegar autochromes remain. The additional six include studies of his wife, Luise, and their children, a still life and a house exterior. All are in the collection of the Provincial Archives of Alberta, with the exception of one in the collection of the Edmonton Art Gallery. Four colour reproductions are found in Skidmore 2003. 
entirely absent from the government pamphlet Kanada, published twenty-five years after the Riel Rebellion. The autochromes affirm that the attraction of a modern, industrializing, agricultural-based society, spiced with the characters of historical imagination, was evocative and enticing for a university-educated, well-travelled, cosmopolitan European man seeking the life of a country gentleman in the colonies.

The Wild West and Musical Ride performances of the summer of 1914 were not Viewegar's first encounter with the legendary West, however. In 1890, he had seen Buffalo Bill's troupe when the Wild West performed in Leipzig. Viewegar's interest and imagination were clearly engaged when he chanced upon the show again in the real geographical space of its narrative, a space historically distanced, however, from the days of the frontier as evidenced by the presence and modernity of cities such as Edmonton. The Edmonton audience and newspapers greeted the Wild West with anticipation and enthusiasm (Edmonton Journal July 22, 1914: 6). Buffalo Bill himself, Colonel William Cody, was photographed for stories in the local papers and he had used photography to publicise his show from its founding in 1883 (Bara 1996; Kasson 2000: 177-181). He is not present in the group gathered for Viewegar's autochrome, however; only the Native American performers are there. Cody's absence from Viewegar's autochrome suggests that it was the spectacle of the Native American performers, their colourful beaded costumes, feathered headdresses, braided hair, and brown skin tones, that engaged the aesthetic sensibilities of the pictorialist photographer interested in the expressive potential of the medium. At the same time, the heightened verisimilitude of Viewegar's colour photographs of western icons would seem to lend documentary authority and historical truth to the two-centuries-old European imaginings and representations of Aboriginal North Americans and conquest of the frontier. ${ }^{10}$

In many ways, Viewegar was visually documenting and preserving the West he had imagined and found again in the spectacles of "Show Indians," American military scouts, and Canadian mounted police who performed the legends of what they had been. At the same time, his path crossed that of Cree Aboriginals whose lives were lived outside the spotlight, as present reality rather than performance of a

10. The impact of Buffalo Bill's Wild West on European immigrants' expectations of North America is discussed in Slotkin (1982: 43). 


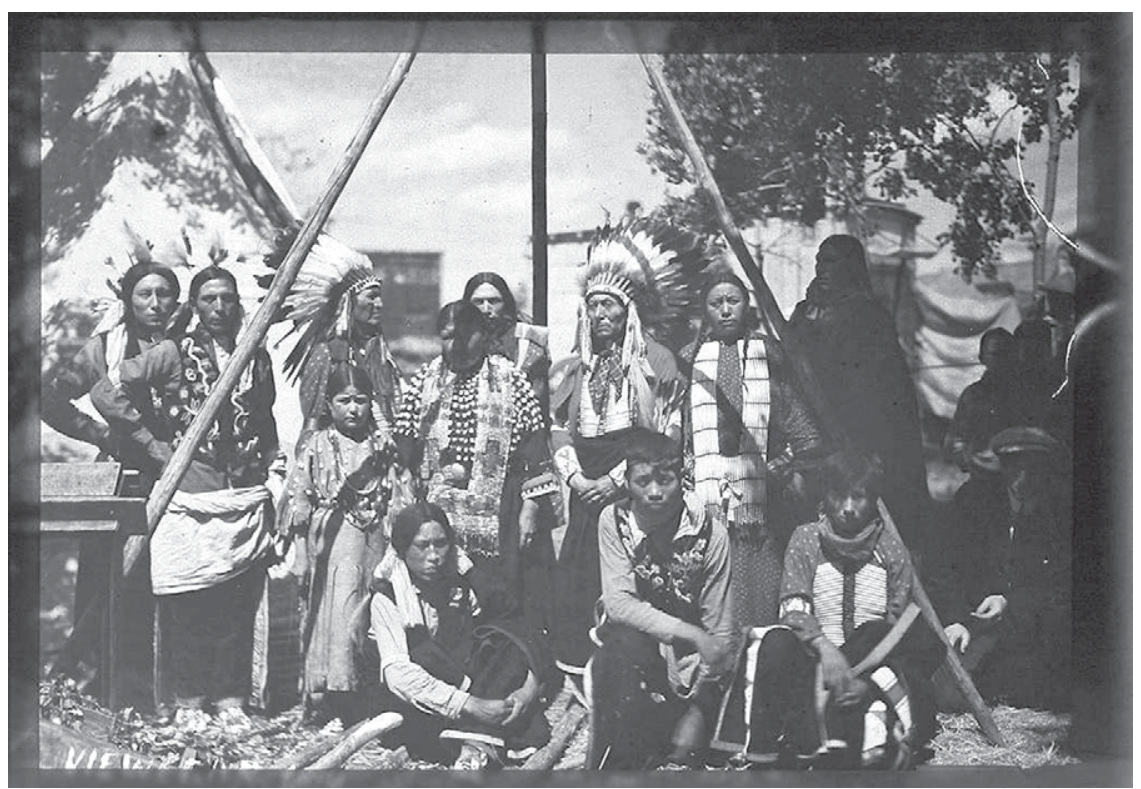

Figure 3. Hugo Viewegar, Buffalo Bill's Wild West Troupe, autochrome, 1914. Edmonton, with permission of the Provincial Archives of Alberta (PR2000.1304.1).

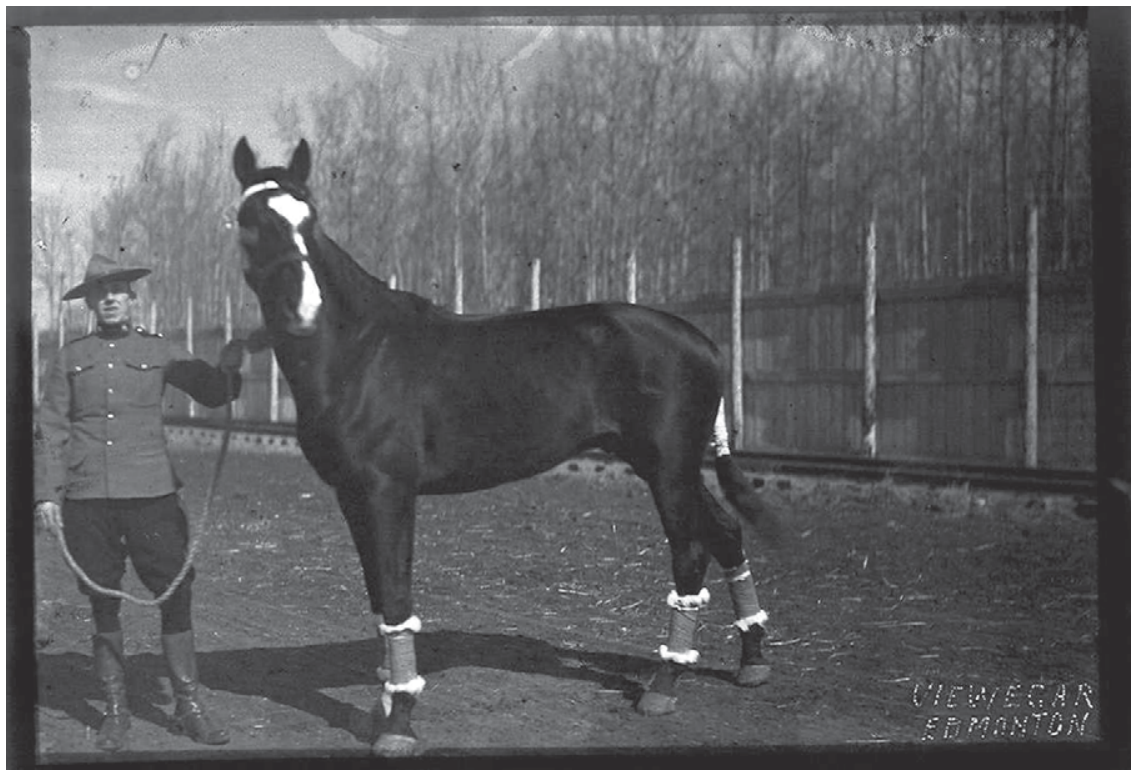

Figure 4. Hugo Viewegar, Royal Northwest Mounted Police Officer and Horse, autochromes, 1914. Edmonton, with permission of the Provincial Archives of Alberta (PR2000.1304.2). 
mythologized past. The autochromes seem to offer the Cree family as evidence that Aboriginals remained real-life characters in the west. While Viewegar framed and exposed the photographs of the Cree family, he and the family members together produced an expressive portrait that profoundly marks the ambiguity of the "reality" rendered. On the one hand, the intact portrait, arranged in the traditional European pictorial manner as a stable triangular form, presents the family as evidence of the successful instigation and integration of western European ideals and values in Aboriginal culture as a model patriarchal, nuclear family. Furthermore, the sophisticated photographic medium used to represent the Europeanisation of western North American culture - like the trains, bridges and architecture demarcating the urban space - is subtle physical evidence of the modernity of that time and place, as a site of both advanced photographic technology and cosmopolitan fine art.

On the other hand, given the family's contribution to the standard portrait composition, the autochromes make visible the sharp contrast of the romantic ideal embodied by the Wild West "Show Indians" with the contemporary reality of Treaty Indians on the Canadian prairies. The dire social and economic consequences of 150 years of CreeEuropean political, economic, and social relations is distressingly rendered by the images of the family. The fluidity of meaning is all the more apparent when we consider the disparate cultural and ethnic lines of sight that meet in the space claimed by British imperial action. From the viewpoint of the non-British European immigrant, the image resonates with both the dominant European culture's imagined West and the dissonance of that mythology with the reality encountered, but not recounted in immigration promotion, in the Canadian West. From the viewpoint offered by the Cree family, the autochrome discloses Aboriginal perspectives of the same historical space as markedly diverse, and elusive to documentation by traditional, material European methods of image and text.

The common historical space occupied by Viewegar and the family was brief, little longer than the time taken to make the autochromes. On August 4, Britain declared war on Germany, and Canada immediately enacted the War Measures Act. Editorials in the Edmonton Bulletin (1914: 4) and the Edmonton Journal admonished readers to recall that German immigrant residents had been welcome, contributing citizens and argued that they deserved tolerance rather than hostility. 
[C]are should be taken not to give needless offense to the German citizens of the country... As citizens of a British country they enjoyed freedom and prosperity and they were altogether as one with the rest of Canada in wishing for a complete Hohenzollern defeat. This is the attitude of a larger proportion of our people of German antecedents than most of us are aware (1914: 4).

Nevertheless, their status as settler immigrants inverted to "enemy alien." ${ }^{11}$ German immigrants were no longer eligible for work and, as was Viewegar's experience, their property could be seized and confiscated, and they could be relocated. Viewegar and his family moved to a homestead near Edgerton, Alberta, 244 kilometres southeast of Edmonton where they remained under RCMP surveillance for the duration of the war (Vieweger 2001: 25). The toll on the family was great. Luise died three years later, still in her thirties. Viewegar continued to raise the children on his own on the Edgerton area farm. He never returned to a serious photography practice and died there impoverished in 1930.

Given recognition of the costs and consequences of imperialism and treaties for the Cree family in historical retrospect, what is the perception of the fate that awaited the German immigrant enticed to a challenging, emerging region? While difficult to muster similar sympathy for a prosperous man with the means to pursue his dream, the extraordinary consequences of the War Measures Act, the hard physical challenges of farming on the Canadian prairies in the 1920s, the loss of Luise, and the dissipation of the family patrimony are testament to both the secondary status of non-British immigrants and the meagre foundations of the promises made about the Land of Opportunity to those on the margins of colonial societies invited to settle the historical space. The fragile autochromes that render visible the common historical space shared by the immigrant photographer and the Aboriginal family are an evocative testament to the complexity and fluidity of the cultural crossroads of the prairie a century ago. No matter the line of sight along which they are viewed, the photographs present the story Eurocolonialist culture was telling about itself, a story in which both Aboriginals and immigrants were integral. What is made visible by the autochromes today are the settler immigrant's recognition of the price paid by Aboriginal societies, and Aboriginal recognition of the benefits

11. "Alien" referred to persons not of British origin (The law and regulations of Canada 1910: 10). 
possessed by settler immigrants. The image renders tangible the space and time in which those whose land and those whose labour constituted the strength and success of the British colonial enterprise in North America met - and held - one another's gaze. 


\section{References}

Bara, Jana L. 1996. "Cody's Wild West Show in Canada." History of Photography 20 (2): 153-55.

Barthes, Roland. 1981. Camera Lucida: Reflections on Photography. New York: Hill \& Wang.

Census of Canada 1911. 1913. Vol. II, Table VII: 162-163. Ottawa. City of Edmonton Archives. n.d. City of Edmonton Population History. Clifford, James, and George E. Marcus, eds. 1986. Writing Cultures: the Poetics and Politics of Ethnography. Berkeley: University of California Press.

Dempsey, Hugh A. 1986. Indian Tribes of Alberta. Calgary: Glenbow Museum.

Department of the Interior. 1910. The law and regulations of Canada.

Ottawa.

Department of the Interior. 1910. Kanada: Das Land Der Gelegenheit.

Ottawa.

Edmonton Bulletin 1914. [No title.] August 10: 4.

Edmonton Journal 1914. "Our German Citizens." August 12: 4.

Edmonton Journal 1914. "Buffalo Bill Heads Street Parade". July 22: 6. Gregoire, Lisa. 2001. "Groups Join Forces to Fight for Their Past." Edmonton Journal, November 6: B1.

Howell, David. 2004a. "Crossroads in Rossdale." Edmonton Journal, April 4: D6-7.

—. 2004b. "Report encourages Rossdale flats memorial." Edmonton Journal, April 6: B3.

Iacovetta, Franca, ed. 1998. A Nation of Immigrants: Women, Workers, and Communities in Canadian History, 1840s-1960s. Toronto: University of Toronto Press.

IWGIA - International Work Group for Indigenous Affairs. 1997. Honour Bound: Onion Lake and the Spirit of Treaty Six. Copenhagen: IWGIA.

Jameson, Elizabeth, and Susan Armitage, eds. 1997. Writing the Range: Race, Class, and Culture in the Women's West. Norman and London: University of Oklahoma Press.

Kasson, Joy S. 2000. Buffalo Bill's Wild West: Celebrity, Memory, and Popular History. New York: Hill and Wang.

King, Thomas. 2003. The Truth about Stories: A Native Narrative. Toronto: House of Anansi Press.

Lippard, Lucy. 1999. On the Beaten Track: Tourism, Art and Place. London: New Press. 
Morris, Alexander. [1880] 1991. The Treaties of Canada With the Indians of Manitoba and the North-West Territories Including The Negotiations on Which They Were Based. Saskatoon: Fifth House Publishers.

Owens, Louis. 2003. "Their Shadows Before Them: Photographing Indians." In Susan Bernardin, Melody Graulich, Lisa MacFarlane \& Nicole Tonkovich eds., Trading Gazes: Euro-American Women Photographers and Native North Americans. New Jersey and London, Rutgers University Press: 186-192.

Phillips, Glen C. 1997. The Western Canada Photographers List (18601925). London, Ontario: Iron Gate Publishing.

Pratt, Mary Louise. 1993. Imperial Eyes: Travel Writing and Transculturation. London and New York: Routledge.

Rutherford, Jonathan. 1990. "The Third Space: Interview with Homi Bhabha." In Jonathan Rutherford ed., Identity: Community, Culture, Difference. London, Lawrence \& Wishart: 207-221.

Skidmore, Colleen. 2003. "Imaging the 'Wild West': Hugo Viewegar and the Autochrome in Canada." History of Photography 27 (4): 342-348.

Slotkin, Richard. 1982. "The 'Wild West”. In David H. Katzive, ed., Buffalo Bill and the Wild West. Pittsburg, University of Pittsburg Press: 27-44.

Sontag, Susan. 1973. On Photography. New York: Ferrar, Straus and Giroux.

Tichenor, Harold. 2002. The Blanket: An Illustrated History of the Hudson's Bay Point Blanket. Toronto: Madison Press Books.

Vieweger, Dale. 2001. Triumph and Tragedy. Unpublished manuscript. Wissler, Clark. [1915] 1975. Costumes of the Plains Indians Together With Structural Basis to the Decoration of Costumes Among the Plains Indians. New York: AMS Press.

Wood, John W. and Merry A. Foresta. 1993. The Art of the Autochrome: the Birth of Color Photography. Iowa City: University of Iowa Press. 